\title{
Refractory Spindle Cell Sarcoma
}

National Cancer Institute

\section{Source}

National Cancer Institute. Refractory Spindle Cell Sarcoma. NCI Thesaurus. Code C158431.

Spindle cell sarcoma that is resistant to treatment. 